\title{
4th Summer School on Speleothem Science (S4)
}

\author{
Brittany Marie Ward ${ }^{1}$, T. Pollard ${ }^{2}$, E. Corrick ${ }^{2}$ and O.A. Dumitru ${ }^{3}$ \\ Cluj-Napoca, Romania, 11-17 August 2019
}

Speleothem science is a rapidly growing discipline in the field of paleoclimatology. The application of speleothem-based research includes diverse topics such as the reconstruction of sea-level rise (Dumitru et al. 2019), assessment of monsoon dynamics (Dykoski et al. 2005), exploration of humanclimate relationships (Pickering et al. 2019), calibration of the radiocarbon timescale (Noronha et al. 2014), precisely dating of the timing of global abrupt climate changes (Moseley et al. 2014), and many more. The necessity of a student-focused training school on this topic was acknowledged in 2011 by a group of PhD students, who went on to hold the inaugural Summer School on Speleothem Science (S4) in Heidelberg, Germany, in 2013. At its core, S4 has remained a student-led initiative and was subsequently held in Oxford, UK (2015) and Burgos, Spain (2017).

The fourth iteration of S4 was hosted at the Babeș-Bolyai University in ClujNapoca, Romania, from 11-17 August 2019 (speleothemschool.com). The school was the largest S4 yet, with 63 early-career participants from 24 countries, as well as 19 invited lecturers, in attendance. The four-day academic program consisted of lectures, workshops, a career development panel and two poster sessions, in which participants presented their current research. The academic component of the school covered fundamental aspects of speleothem science in a lecture format, generated valuable discussion between participants and experts during question periods, and aimed to create a welcoming atmosphere to integrate early-career speleothem researchers into the field of speleothem science. The lecture program covered fundamental topics in speleothem science, such as speleothem formation and stable isotope analysis, but also included discussion of frontier research topics, such as characterization of cavesystem hydrology using advanced geophysical imaging methods, exploration caving being undertaken in Northeast Greenland, and new speleothem drip-rate proxies based on the dissociation kinetics of trace metalorganic ligand complexes. The workshop program also introduced participants to a selection of software packages relevant to the field, including COPRA (depth-age modeling software), PHREEQC (geochemical modeling), and CaveCalc (cave drip water and speleothem chemistry modeling), as well as a hands-on session on uncertainties in timeseries analysis.

The academic program was followed by a two-day field trip to the Apuseni Mountains of Transylvania. Participants were guided by Babeș-Bolyai University and Emil Racoviță Institute of Speleology researchers to Transylvania's impressive karst landscape, visiting the world-renowned Meziad Cave, Bears' Cave (Fig. 1), and the impressive Scărișoara Ice Cave. Participants were able to gain an appreciation of speleothem formation environments, see examples of

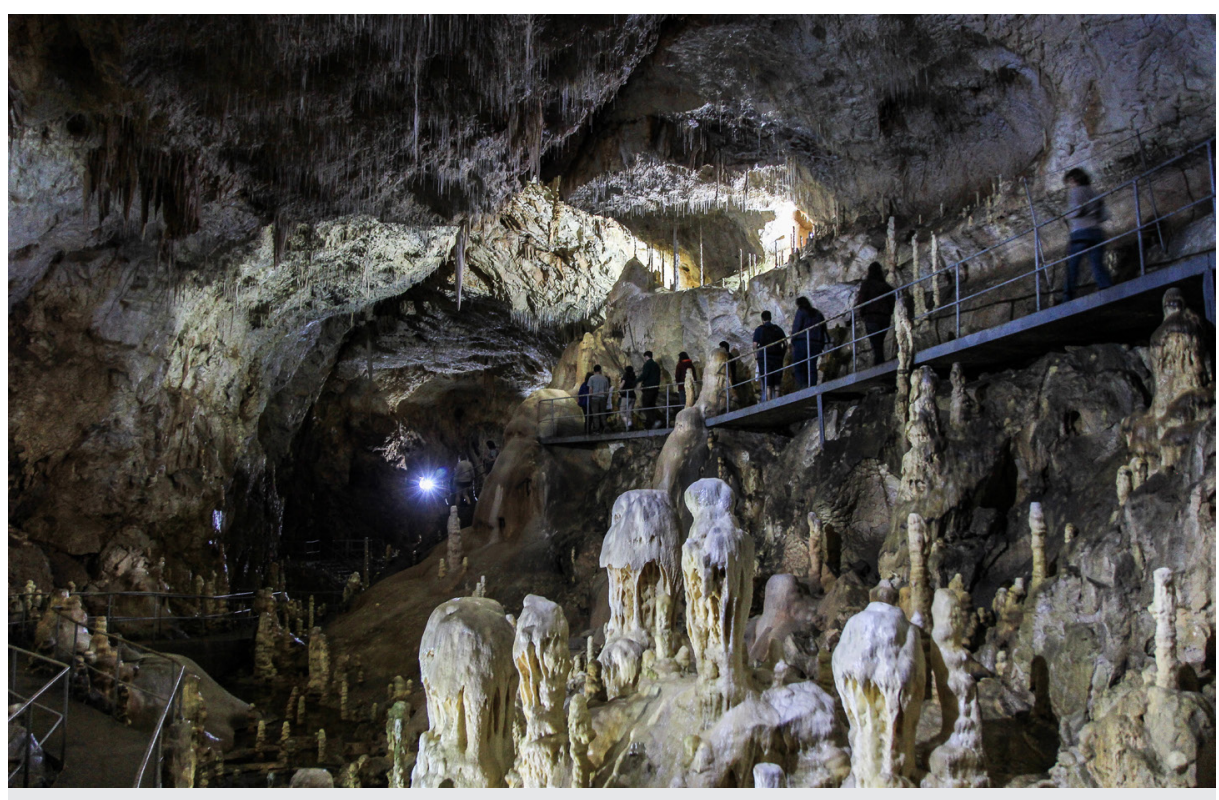

Figure 1: S4 2019 participants touring the immaculately decorated Bears' Cave of Chişcău, Romania, where Emil

Racoviță Institute of Speleology researchers are undertaking cave sediment and paleontological research. cave monitoring stations, practice interpreting stalactite patterns on the cave roof, and see firsthand a $15 \mathrm{~m}$-thick cave glacier that has yielded a 10,000-year-old paleoclimate record. Participants came together for a traditional Romanian dinner during the field trip in the Hotel Perla Apusenilor and were treated to a performance of Romanian folk music with alphorns.

The 2019 Organizing Committee aims to provide lasting resources to S4 2019 participants and other speleothem researchers by sharing the S4 2019 Course Notes, which are now available via the S4 ResearchGate profile (researchgate.net/ project/Summer-School-on-SpeleothemScience). Further, the $\mathrm{S} 4$ aims to establish a strong social media presence on both Twitter and Instagram. These platforms can be used to advertize upcoming workshops in the broader field of speleothem science, highlight new research and generate discussion within the community, spread the word of PhD, postdoctoral, and faculty positions, and share stories from the lab and the field. Follow S4 at @SumSchSpelScion Twitter and @s4_speleothem on Instagram.

The S4 provides a unique opportunity for international networking in a casual and inclusive setting, fostering relationships between early-career researchers, and bringing together the future of Speleothem Science. We look forward to passing the torch to the S4 2021 Organizing Committee.

\section{ACKNOWLEDGEMENTS}

We thank the Babeș-Bolyai University, PAGES, the International Association of Sedimentology (IAS) and the European Geoscience Union (EGU) for their financial and logistical support that made this event possible.

\section{AFFILIATIONS}

${ }^{1}$ Environmental Research Institute, University of Waikato, New Zealand

${ }^{2}$ School of Geography, The University of Melbourne, Australia

${ }^{3}$ School of Geosciences, University of South Florida, USA

\section{CONTACT}

Brittany Marie Ward: brimward@gmail.com

\section{REFERENCES}

Dumitru OA et al. (2019) Nature 547: 233-236 Dykoski CA et al. (2005) Earth Planet Sc Lett 233: 71-76 Moseley GE et al. (2014) Geology 42: 1043-1046 Noronha AL et al. (2014) Earth Planet Sc Lett 394: 20-29 Pickering R et al. (2019) Nature 565: 226-229 